\title{
Dampak Psikologis Peserta Didik yang Menjadi Korban Cyber Bullying
}

\author{
Desiana Risqi Hana ${ }^{1}$, Suwarti ${ }^{2}$ \\ Fakultas Psikologi, Universitas Muhammadiyah Purwokerto \\ ${ }^{1}$ desianarisqi1@gmail.com, ${ }^{2}$ suwartidarman@gmail.com
}

\begin{abstract}
Abstrak
Penelitian ini bertujuan untuk mengetahui dan menggambarkan dampak psikologis pada peserta didik yang menjadi korban cyberbullying. Penelitian ini menggunakan pendekatan kualitatif dengan pendekatan studi fenomenologi. Data dikumpulkan melalui metode wawancara dan dokumentasi pada 11 orang, dengan rincian 7 orang informan primer dan 4 orang sebagai informan sekunder. Validitas yang digunakan dalam penelitian ini adalah triangulasi teknik. Berdasarkan hasil penelitianditemukan adanya dampak psikologis akibat cyberbullyingyang dialami oleh korban. Dimana terdapat tiga dampak kognitif yaitu dampak kognitif, afeksi, dan konatif. Dampak kognitif yang dialami adalah kehilangan konsentrasi belajar dan mengalami penurunan indeks prestasi sekolah. Dampak afeksi yang dialami adalah merasa marah, malu, dendam, risih, dan kehilangan kepercayaan. Dampak konatif yang dialami adalah membalas pelaku dengan perlakuan yang sama seperti memposting foto jelek pelaku dan juga membalas dengan kekerasan fisik seperti memukul, melempar, dan membanting barang. Ada juga yang hanya memendam amarah dan memilih untuk menghindari pelaku. Hingga melaporkan kepada orang tua dan guru Bimbingan Konseling serta memutuskan hubungan komunikasi melalui media sosial dengan pelaku.
\end{abstract}

Kata kunci : Cyber bullying, Dampak psikologis, Peserta didik

\section{Pendahuluan}

Media sosial merupakan salah satu bentuk teknologi informasi dan komunikasi masa kini. Melalui media sosial memungkinkan informasi dapat menyebar dengan mudah di masyarakat. Serta informasi dalam media sosial dapat menyebar dengan mudah dan cepat sehingga mempengaruhi cara pandang, gaya hidup, serta budaya manusia. Melalui media sosial, manusia juga diajak berdialog, mengasah ketajaman nalar dan psikologisnya dengan alam yang tampak pada layar. Namun, tidak disangkal bahwa pesan-pesan yang ditayangkan melalui media elektronik ini dapat mengarahkan khalayak, baik ke arah perilaku prososial maupun antisosial (Pandie \& Weismann, 2016). Di Indonesia, dalam UU No. 11 Tahun 2008 
PSISULA : Prosiding Berkala Psikologi

Vol. 1, 2019

E-ISSN: 2715-002X

tentang Informasi dan Transaksi Elektronik (ITE) yaitu siapa saja yang dengan sengaja dan tanpa hak mendistribusikan informasi elektronik yang melanggar kesusilaan, akan dipidana dengan penjara paling lama 6 tahun dan/atau denda paling banyak satu miliar rupiah. Perangkat hukum ini sebenarnya telah mengakomodir perlindungan dari kekerasan yang dilakukan melalui media sosial (Malihah \& Alfiasari, 2018).

Namun, kenyataannya kini banyak yang menyalahgunakan media sosial untuk melakukan penyelewengan bahkan mengakibatkan munculnya kekerasan. Salah satu bentuk kekerasan yang sering dialami dalam dunia maya adalah cyber bullying (Sari, 2017). Cyber bullying diklasifikasikan ke dalam perilaku bullying, Cyber bullying merupakan hal baru dari perilaku bullying dengan karakteristik dan akibat yang sama. Cyber bullying biasanya dilakukan oleh orang yang sudah dikenal korban di dunia nyata, atau dapat dikatakan bahwa cyber bullying adalah perpanjangan dari tradisional bullying (Ningtyas, 2012).

Berdasarkan studi pendahuluan peneliti melakukkan observasi dan wawancara kepada dua informan.Informan pertama berinisial $\mathrm{N}$, informan merupakan salah satu peserta didik di SMP N 2 Purwokerto. N mendapat pesan didalam grup kelas melalui whatsapp dengan kata-kata kasar seperti "laknat", "anjing" dikarenakan pada saat informan $\mathrm{N}$ memberikan informasi yang diperintahkan oleh guru disampaikan dengan suara yang keras. Dan menerima pesan didalam chatting grup whatsapp bahwa teman-teman kelas informan $\mathrm{N}$ meminta untuk mengganti bendahara kelasnya karena tidak mau memiliki bendahara yang galak. Hingga membuat $\mathrm{N}$ merasa kesal, merasa sedih, merasa tertekan, menjadi beban pikiran, sering murung, menghindar dari anak-anak kelas informan $\mathrm{N}$, dan merasa takut setiap kali membaca chatting tersebut pada akhirnya $\mathrm{N}$ memutuskan untuk keluar dari grup whatsapp kelas $\mathrm{N}$. Bahkan informan $\mathrm{N}$ sempat merasa tidak semangat masuk sekolah, karena $\mathrm{N}$ kembali teringat kenangan masa lalunya sewaktu SD dimana saat itu $\mathrm{N}$ pernah dikucilkan guru dan temantemannya. Informan kemudian mengikuti aktifitas di sekolah seperti mengikuti Olimpiade Sains Nasional, mengikuti ekstrakurikuler di sekolahnya, dan juga 
PSISULA : Prosiding Berkala Psikologi

Vol. 1, 2019

E-ISSN: 2715-002X

mengikuti program tambahan belajar. Informan sadar bahwa informan harus tetap semangat sekolah. Informan $\mathrm{N}$ harus aktif di kelas agar dikenal oleh guru-guru bahwa dirinya adalah anak yang baik.

Informan kedua berinisial A merupakan peserta didik di SMP N 2 Purwokerto, informan merupakan anak yang pendiam didalam kelasnya. Informan A tidak memiliki teman dan selalu sendirian, bahkan dikucilkan. Teman-teman A sering melakukkan bullying terhadap A tidak hanya bullying langsung namun juga cyber bullying.Setiap selesai sholat dhuhur berjamaah sandal informan sering diinjak-injak oleh teman-teman hingga informan A hampir jatuh bahkan tidak hanya sandal, kaki informan A turut di injak. Selain itu informan A pernah diejek melalui pesan whatsapp seperti dihina "pendek bocil banget", "orang miskin ngapain sekolah disini", dan terkadang mengucapkan kata-kata kasar seperti "jancuk" atau "jud". Informan A mengalami hal tersebut dikarenakan informan A kesulitan untuk mendapatkan teman.

Teman-teman informan A tidak bisa menerima keadaan A karena status ekonomi orang tua informan A. Selain itu, teman-teman A sering mengejek informan A karena A memiliki postur tubuh A yang pendek. Sehingga A tidak memiliki keberanian untuk bergaul dengan teman-teman A. Saat kejadian seperti itu informan A hanya menangis dan menahan amarahnya. Sehingga A sering mengurung diri, melamun, dan gelisah. Kemudian informan A melaporkan kepada guru BK dan menceritakan kepada orang tua A hingga akhirnya informan A memutuskan untuk keluar dari SMP Negeri 2 Purwokerto.

Korban adalah merupakan orang yang mengalami kerugian baik berupa kerugian fisik, mental maupun kerugian finansial atau individu yang menderita jasmani dan rohani sebagai akibat tindakan orang lain yang mencuri pemenuhan kepentingan diri sendiri atau tindakan orang lain yang bertentangan dengan kepentingan dan hak asasi yang menderita (Dayakisni, 2013). Korban cyber bullying(Rahayu, 2012) adalah seorang anak atau remaja mendapat perlakukan tidak menyenangkan seperti dihina, diancam, dipermalukan, disiksa, atau menjadi target bulan-bulanan oleh anak atau remaja yang lain menggunakan teknologi 
PSISULA : Prosiding Berkala Psikologi

Vol. 1, 2019

E-ISSN: 2715-002X

Internet, teknologi digital interaktif maupun teknologi mobile. Sedangkan definisi korban cyber bullying menurut Smith (Hidajat, Adam, Danaparamita, \& Suhendrik, 2015) adalah seseorang yang mengalami kerugikaan atau disakiti dan dilecehkan orang lain dengan sengaja secara berulang-ulang karena kesalahan dari penggunaan teknologi informasi.

Masa remaja awal menjadi masa peralihan dari masa kanak-kanak ke masa remaja. Masa remaja sering diidentikkan sebagai masa individu mulai berusaha mengenal diri melalui eksplorasi dan penilaian karakteristik psikologis diri sendiri sebagai upaya untuk dapat diterima sebagai bagian dari lingkungan. Sebagian remaja mampu melewati masa peralihan ini dengan baik, namun beberapa remaja bisa jadi mengalami kenakalan remaja mulai dari kenakalan ringan hingga kriminal, termasuk di dalamnya kenakalan-kenakalan berbentuk cyberbullying (Malihah, 2018). Dalam perspektif psikologis, peserta didik adalah individu yang sedang dalam proses pertumbuhan dan perkembangan, baik fisik maupun psikis menurut fitrahnya masing-masing.

Arifin (2012) mengatakan sebagai individu yang tengah tumbuh dan berkembang, peserta didik memerlukan bimbingan dan pengarahan yang konsisten menuju kearah titik optimal kemampuan fitrahnya. Dalam perspektif Undangundang Sistem Pendidikan Nasional No 20 Tahun 2003 pasal 1 ayat 4, "Peserta didik diartikan sebagai anggota masyarakat yang berusaha mengembangkan dirinya melalui proses pendidikan pada jalur jenjang dan jenis pendidikan tertentu. Berdasarkan studi pendahuluan diatas, penelitian ini bertujuan untuk mengetahui dan menggambarkan dampak psikologis pada peserta didik yang menjadi korban cyber bullying.

\section{Metode}

Penelitian ini merupakan penelitian kualitatif dengan menggunakan pendekatan studi fenomenologi. Fokus penelitian ini adalah mengkaji dampakdampak psikologis yaitu kognitif, afeksi, dan konatif yang terjadi pada korban cyber bullying. Informan penelitian ini terdapat 276 peserta didik kelas VII. Dalam 
PSISULA : Prosiding Berkala Psikologi

Vol. 1, 2019

E-ISSN: 2715-002X

pengambilan data peneliti melakukkan penyebaran angket screening untuk mendapatkan data peserta didik yang menjadi korban cyber bullying.

Peneliti melakukan penyebaran sebanyak 208 anak. Terdapat 194 angket terisi dan 14 angket yang tidak terisi. Peneliti mendapat 12 peserta didik yang menjadi korban cyber bullying. Namun, hanya 7 peserta didik yang bersedia menjadi informan penelitian. Metode pengumpulan data yang digunakan dalam penelitian ini adalah menggunakan metode wawancara dan dokumentasi. Validitas yang digunakan dalam penelitian ini adalah triangulasi teknik. Analisis data dalam penelitian ini melalui proses yaitu pengumpulan data, reduksi data, penyajian data dan penarikan kesimpulan.

\section{Hasil dan Pembahasan}

\begin{tabular}{|c|c|}
\hline Informan & Dampak Psikologis \\
\hline $\mathrm{GN}$ & $\begin{array}{l}\text { 1. Merasa dendam, marah, dan malu ketika foto dirinya diposting di media } \\
\text { sosial } \\
\text { 2. Hilang rasa kepercayaan dan kepedulian kepada teman GN } \\
\text { 3. Menegur dan memarahi teman GN yang melakukan cyber bullying } \\
\text { 4. GN membalas perlakuan dengan cara membalikkan meja, kursi, dan } \\
\text { 5. Dan juga membalas dengan memposting foto pelaku di media sosial }\end{array}$ \\
\hline DN & $\begin{array}{l}\text { 1. Kehilangan konsentrasi belajar } \\
\text { 2. Merasa marah, malu, dan dendam kepada pelaku } \\
\text { 3. Membalas dengan memposting foto dan mengejek pelaku } \\
\text { 4. Bahkan membalas dengan memukul menggunakan koran, melempar pena } \\
\text { 5. Mem menendang pelaku } \\
\text { 5. Mekir nomor whatsapp pelaku }\end{array}$ \\
\hline LS & $\begin{array}{l}\text { 1. Merasa malu, marah, dan ingin membalas dendam } \\
\text { 2. Merasa kecewa dan hilang kepercayaan kepada pelaku } \\
\text { 3. Menegur pelaku } \\
\text { 4. Menutup diri dan memilih untuk menjadi anak yang pendian di kelas }\end{array}$ \\
\hline IR & $\begin{array}{l}\text { 1. Merasa marah, benci, malu, dan tidak nyaman } \\
\text { 2. Menangis dan takut jika orangtua IR mengetahui cyber bullying yang } \\
\text { dialaminya } \\
\text { 3. IR memilih untuk diam dan memblokir nomor whattsapp pelaku } \\
\text { 4. Menghindari pertengkaran dengan keluar dari grup whattsapp kelas }\end{array}$ \\
\hline $\mathrm{RD}$ & $\begin{array}{l}\text { 1. Menjadi beban pikiran } \\
\text { 2. Merasa terpukul, kehilangan kepercayaan diri, dan merasa sakit hati } \\
\text { 3. Melaporkan kepada orangtua, guru bk, dan orangtua sahabat RD } \\
\text { 4. Hanya membaca pesan yang diterimanya }\end{array}$ \\
\hline MD & $\begin{array}{l}\text { 1. Kehilangan konsentrasi belajar } \\
\text { 2. Merasa sakit hati ketika menerima pesan berisi kata-kata kasar } \\
\text { 3. Merasa tidak nyaman, jijik, gemetar, dan jantung berdetak kencang karena } \\
\text { takut pada pelaku }\end{array}$ \\
\hline
\end{tabular}




\begin{tabular}{|c|c|c|}
\hline & $\begin{array}{l}4 . \\
5 .\end{array}$ & $\begin{array}{l}\text { Memblokir whatsapp pelaku } \\
\text { Menghindari pelaku hingga membolos kegiatan ekstrakurikuler }\end{array}$ \\
\hline OA & $\begin{array}{l}1 . \\
2 . \\
3 . \\
4 .\end{array}$ & $\begin{array}{l}\text { Kehilangan konsentrasi belajar hingga mengakibatkan nilai OA mengalami } \\
\text { penurunan } \\
\text { Merasa sakit hati ketika menerima pesan dengan kata-kata yang kasar } \\
\text { Merasa tidak nyaman, jijik, dan takut kepada pelaku } \\
\text { Mengatasi permasalahan dengan memblokir nomer whatsapp dan } \\
\text { melaporkan kepada guru bimbingan konseling }\end{array}$ \\
\hline
\end{tabular}

Menurut Faucher dkk (Syadza \& Sugiasih, 2017) kurangnya kebijakan hukum menyebabkan pelaku mudah untuk menangkis tuduhan tersebut dengan mengatakan bahwa apa yang di lakukannya tersebut hanyalah sebuah lelucon. Banyak peraturan yang ada hanya sebatas penghinaan, intimidasi dan pelecehan yang dilakukan secara langsung, bukan melalui media online. Namun, pendapat Beran \& Li (Sartana \& Afriyeni, 2017) mengatakan bahwa seseorang yang menjadi korban cyber bullying akan memiliki kesulitan dalam berkonsentrasi. Semakin sering korban memperoleh perlakuan cyber bullying maka akan semakin memberikan dampak buruk pada diri korban di dalam kehidupan.

Seperti hasil temuan saat RD mengalami cyber bullying seperti mendapat pesan berupa kata-kata kasar dari pelaku seperti "brengsek" menjadikan beban pikiran RD hingga akhirnya membuat RD tidak memikirkan tindakan cyber bullying yang dialaminya karena menganggap bahwa tindakan tersebut tidaklah sesuatu yang penting. Serta yang cyber bullying yang dialami DN, MD, dan OA juga mengalami kehilangan konsentrasi belajar hingga menurunkan indeks prestasi di sekolah. Hingga MD dengan sengaja membolos dalam pertemuan ekstakurikuler yang diikutinya karena takut bertemu dengan pelaku.

Beran et al., (Syah \& Hermawati, 2018) membuktikan, bahwa korban cyber bullying mempunyai pengalaman buruk berupa dimarahi orang lain di dunia online dapat menyebabkan hilangnya kepercayaan, atau mereka sebagai korban akan menjadi cyberbullies atau terus menjadi korban. Selain itu, ketika kekerasan secara online terjadi korban hingga menangis, merasa malu, kehilangan teman di sekolah, tertekan, dan mengalami insomnia setelah perlakuan cyber bullying. 
PSISULA : Prosiding Berkala Psikologi

Vol. 1, 2019

E-ISSN: 2715-002X

Off \& Mitchell (dalam Syah \& Hermawati, 2018) melaporkan ketika korban tidak tahu dirinya diserang, maka ketakutan dan kemarahan akan meningkat. Hal ini seperti dalam hasil wawancara dimana terdapat dampak afeksi yang dirasakan setelah mengalami adanya tindakan cyber bullying seperti merasa sakit hati, marah, dan dendam karena menerima perkataan yang kasar atau komentar nagatif seperti "berengsek, bajingan, setan, tuman" melalui media sosial.

Adapula timbulnya perasaan malu yang dirasakan oleh GN, DN, LS, dan IR karena foto-foto yang disebarkan melalui media sosial. Merasa risih terhadap pesan-pesan yang diterima dan berhubungan dengan pelecehan seksual yang dialami oleh IR, MD, dan OA. Hingga merasa badan MD merasa gemetaran dan jantung berdebar-debar karena merasa takut bertemu dengan pelaku. Tak hanya itu hingga menyebabkan hilangnya kepercayaan dan rasa peduli kepada teman yang dilami oleh GN, DN, dan RD.

Hal tersebut menunjukan bahwa cyber bullying berdampak pada perubahan emosi. Hal ini didukung oleh pendapat Nurihsan \& Agustin (2013), bahwa remaja (SMP) sering kali mudah marah, mudah tersinggung, mudah dirangsang, dan emosinya cenderung meledak dan tidak berusaha mengendalikan perasaaanya (mengontrol emosi). Dampak atau kondisi psikologis korban dapat dilihat dari penelitian yang dialkukan oleh Riauskin \& Soestio (2005), yang menemukan bahwa korban merasakan banyak emosi negatif seperti marah, dendam, kesal, tertekan, takut, malu, sedih, tidak nyaman, dan terancam dan bahkan ditemukan pula korban yang merasa tertekan takut bertemu dengan pelaku bullying hingga depresi dan berkeinginan untuk bunuh diri.

Umumnya, korban fokus untuk menyingkirkan hal-hal negatif dengan "memblokir" pelaku, "mengabaikan" pendapat, mengurangi penggunaan media sosial, atau "menghapus" konten. Hal tersebut merupakan cara sopan untuk menghadapi dan tidak membalas pelaku. Meskipun terdapat sebagian korban yang langsung menghadapi pelaku. Konfrontasi langsung ini terjadi ketika korban memiliki hubungan pribadi dengan pelaku. Konfrontasi langsung terkadang 
PSISULA : Prosiding Berkala Psikologi

Vol. 1, 2019

E-ISSN: 2715-002X

menyebabkan timbal balik yang negatif terhadap pelaku (Gahagan, Vaterlaus \& Frost, 2016).

Terbukti dari hasil wawancara yang dilakukan berdasarkan dari adanya dampak kognitif dan afeksi membentuk suatu dampak konatif yang terjadi kepada GN, DN, LS, IR, RD, MD, dan OA dimana langsung menegur, hingga memarahi pelaku setelah mengalami cyber bullying. LS, IR, dan RD yang memilih untuk diam dan tidak ikut campur permasalahan yang terjadi karena tidak mau semakin memperkeruh keadaan. OA melaporkan pelaku kepada guru BK untuk menyelesaikan masalah yang dihadapinya. Serta IR, OA, dan MD memutuskan komunikasi dengan cara memblokir nomor whatsapp pelaku.

Ketika tindakan yang dilakukan tidak berpengaruh terhadap pelaku kemudian GN dan DN membalas perlakuan yang dialaminya dengan menjadi pelaku cyber bullying dan membalas dengan mengamuk seperti membating, melempar, memukul dengan barang-barang. Sesuai dengan penelitian yang dilakukan oleh Beran dan Li (2007) menunjukkan bahwa siswa yang ditindas di dunia maya juga cenderung untuk menyerang rekan-rekannya di dunia maya dan diganggu di sekolah (56\%).

\section{Kesimpulan}

Berdasarkan hasil penelitian dan pembahasan dari dampak-dampak psikologis pada korban cyber bullying menunjukan bahwa informan memiliki dampak-dampak psikologis yaitu dampak kognitif, afeksi, dan konatif. Dampak kognitif yang dialami yaitu kehilangan konsentrasi belajar hingga menurunkan indeks prestasi sekolah. Dampak afeksi yang dialami yaitu merasa sedih, marah, malu, dendam dikarenakan mendapat komentar dan pesan dengan kata-kata kasar melalui sosial media seperti "brengsek, bangsat, setan, tuman", hilangnya kepercayaan, tidak nyaman, dan takut karena menerima pesan melalui media sosial dengan motif pelecehan seksual. Hal ini terus berkaitan dan kemudian menyebabkan dampak konatif yang dialami. Dampak konatif yang dialami yaitu membalas dendam seperti membalas dengan memposting foto pelaku, menegur 
PSISULA : Prosiding Berkala Psikologi

Vol. 1, 2019

E-ISSN: 2715-002X

hingga membalas dengan menggunakan kekerasan fisik seperti memukul, melempar, dan membanting benda-benda, ada yang memilih untuk diam dan memendamnya sendiri, menjauhi dengan memutuskan semua akses untuk berkomunikasi seperti memblokir nomor whatsapp dan keluar dari grup di media sosial, dan melaporkan kepada Orang tua serta guru Bimbingan Konseling.

\section{Daftar Pustaka}

Arifin, Z. 2012. Psikologi Perkembangan Peserta Didik. Bandung: PT Remaja Rosdakarya.

Beran, T., \& Li, Q. (2007). The Relationship Between Cyberbullying and School Bullying. Journal of Student Wellbeing, 1, (2), 15-33.

Gahagan, K., Vaterlaus, J. M., \& Frost, L. R. (2016). Computers in Human Behavior College Student Cyberbullying on Social Networking Sites: Conceptualization, Prevalence, and Perceived Bystander Responsibility. Journal of Computers in Human Behavior, 55, 1097-1105.

Hidajat, M., Adam, A. R., Danaparamita, M., \& Suhendrik. (2015). Dampak Media Sosial Dalam Cyberbullying. ComTech, Vol.6, No.1 , 72-81.

Malihah, Z., \& Alfiasari. (2018). Perilaku Cyberbullying pada Remaja Dan Kaitannya dengan Kontrol Diri dan Komunikasi Orang Tua. Jurnal Ilmiah Keluarga dan Konseling Vol.11, No.2 .

Ningtyas, K. A. 2012. Hubungan antara Pola Penggunaan Situs Jejaring Sosial Facebook dengan Kerentanan Cyber Harrasment pada Anak. Skripsi. Universitas Indonesia. Depok

Pandie, M. M., \& Weismann, I. (2016). Pengaruh Cyberbullying di Media Sosial terhadap Perilaku Reaktif sebagai Pelaku Maupun sebagai Korban Cyberbullying pada Siswa Kristen SMP Nasional Makassar. Jurnal Jaffray Vol. 14, No. 1.

Rahayu, F. S. (2012). Cyberbullying sebagai Dampak Negatif Penggunaan Teknologi Informasi. Journal Information Systems Vol. 8, No. 1.

Sari, D. P. (2017). Keterbukaan Diri pada Remaja Korban Cyberbullying. Jurnal Psikoborneo , 5, (1).

Sartana, \& Afriyeni, N. (2017). Perilaku Perundungan Maya (Cyberbullying) pada Remaja Awal. Jurnal Psikologi Insight, Vol. 1(1), 25-41. https://doi.org/10.5281/zenodo.576972

Syah, R., \& Hermawati, I. (2018). Upaya Pencegahan Kasus Cyberbullying bagi Remaja Pengguna Media Sosial di Indonesia. Jurnal PKS, Vol. 17 , 131-146.

Syadza, N., \& Sugiasih, I. (2017). Cyberbullying pada Remaja SMP X Ditinjau dari Konformitas dan Kematangan Emosi. Jurnal Proyeksi, Vol. 12, No. 1 , 17-26. 